\title{
語られないことの理解 認知症の残存機能
}

緑川晶

\section{はじめに}

認知症は、発症とともに記憶をはじめとして 様々な認知機能が障害されるが、障害されるの は認知機能だけにとどまらず、それまでの地位 や名声、あるいは他者との関係など様々なこと をその人から奪っていく。しかし筆者の臨床経 験からも、また望まれる認知症ケアなどの言説 からも（例えば [1] など）、たとえ認知症とな り、症状が進んだとしても主観的な世界は存在 し、周囲を知覚あるいは認識していると思われ る。ただ、その世界は私たちのそれとは大きく 異なっているのかもしれない。また適切な認知 や表出ができないがために、それを伝えること も難しい状態かもしれない。

これまでにも認知症当事者の手記(例えば $[2,3]$ など）によって、そのような当事者の内的世界を 垣間見ることができたが、より症状が進んだ人々 の世界を知ることは容易ではない。そのため、 周囲の人々はそのような主観的な世界の存在を
見過ごしたまま対応してしまうことが少なくな いと思われる。神経心理学の領域も例外ではな く、学術的あるいは臨床的な要請から、障害さ れた能力の評価には多くの関心が向けられてき たが、当事者のできること、或いは残されてい ることについて議論がなされることは極めて稀 である。本稿は、そのような当事者の世界につ いて、神経心理学をべースに様々な角度から理 解を試みようとしたものである。

\section{認知症と自覚}

認知症の当事者が自らの主観的な世界を表現 することが難しいのは、単に認知機能の低下に よって表現する手段が制限されていただけでは なく、認知症の方々の認識そのものにも変化が 生じるからでもある。

認知症の診断基準には、記憶障害をはじめと して各種の認知機能の低下が示されているが (表1） ${ }^{4}$ 、このような認知機能の低下だけではな

表 1 認知症の診断基準（文献[4]より）

A. 1つ以上の認知領域（複雅性注意，遂行機能，学習および記憶，言語，知覚一運動，社会的認知）において, 以前の行為水準から有意な認知の低下があるという証拠が以下にもとづいている：

（1）本人，本人をよく知る情報提供者，または臨床家による有意な認知機能の低下があったという懸念，および

（2）標準化された神経心理学的検査によって,それがなければ他の定量化された臨床的評価によって記録された, 実質的な認知行為の障害

B. 毎日の活動において，認知欠損が自律を阻害する（すなわち，最低限，請求書を払う，内服薬を管理するなど

の，複雑な手段的日常生活動作に援助を必要とする).

C. その認知欠損は， せん妄の状況でのみ起こるものではない

D. その認知欠損は，他の精神疾患によってうまく説明されない（例：うつ病，統合失調症). 
く、認知症ではその低市にういで認識すなわ ち病識の低下も生じている。たとえば、中高年 以上になると加齢にともなって人の名前などの 覚えの悪さを自覚することがあるが、そのよう な生理的健忘は認知症における健忘とは異なっ た性質であると言われ、その鑑別ポイントの一 つとして、自覚の低下が認知症の特徽として挙 げられている5。な㧍、最近では、このような自 覚のそしさは、認知症が発症するよりも前から 生じている可能性が示されて扔り（図1）崖、メ 夕な認識の変化が認知症の本質の一つと考元ら れる。

ただ、必ずしも認知症は自覚の低下を引き 起こすとは限らない。認知症はその病因の多様 性だけではなく、同じ病因でも障害される脳領 域によって様々なバリエーションが生じるこ とが知られているが、そのようなバリエーショ ンの一つに後方皮質萎縮症（Posterior Cortical

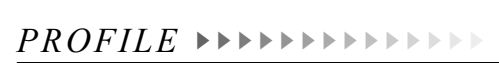

- 中央大学文学部教授

專門 神経心理学
緑川晶(みどりかわ あきら)

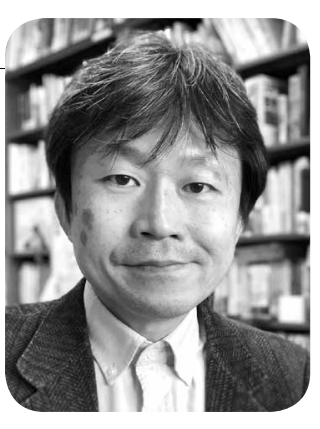

Atrophy：PCA）がある。PCAは病理学的な背 景はアルッハイマー病であることが多いが、ア ルッハイマー病の典型的な臨床像とは異なり、 脳の後頭葉や頭頂葉の萎縮と、記憶の低下に比 較して視空間機能や視知覚能力の障害が目立つ 点を特徴としている。また、自己の状態に対す る洞察力 (病識) も保たれていることが知られ ている7。このように病識があり、見づらさの原 因を自ら探ろうとするために、眼鏡店に行って は何度も眼鏡を作り直したり、見えの違和感を 神経内科ではなく眼科で訴えたりするために、 診断までに時間がかかることも少なくなく、ま た、自覚があるために抑うつが強いことも報告 されている8。

筆者が経験した症例 ${ }^{9}$ も、受診のきっかけを 問うと「目が疲れやすくなっ たり、目がチカチカしたり、 それがおかしいなと思って 眼科に行きました」と答え、 病院で受けた認知機能検査 の感想を問うと「ここは残っ ている、ここは衰えている なという意識をしながら受 けました」と答え、病気で あると診断されたあとの感 想を問うと「苦にしない性 格なので受け入れちゃう。 出来ないことはできない。 
どうしようもない」と答えるように、病識が保 たれているだけではなく、障害の理解や受け止 めも適切になされ、今後を案じて、経営してい た商店も自らの判断で閉じることを決定したり もしていた。

認知症の当事者がここまで自身の状態を把握 しそれを語ることは稀であろう。しかし様々な 手法を通じて、認知症の方々の内面を伺い知る ことができるのではないか、というのが筆者の 立場である。以下にその例を紹介する。

\section{描画から見えてくること}

認知症の検査の一つに時計描画課題がある。 指示された時間を針と文字盤によって表すこと が求められ、 $\mathrm{MoCA}^{10}$ や $\mathrm{GPCOG}^{11} 、 \mathrm{Mini}^{-\mathrm{Cog}^{12}}$ ど多くの認知症スクリーニング検査でも採用さ れている課題である。この課題が記憶課題と共 にスクリーニング検査の中核となることからも、 認知症患者の多くで描くことの困難が生じてい るとも言える。一方で、認知症になってからも 描くことが可能であったり、あるいは発症後に 描画の向上が見られるという報告が散見される。 次の症例も、そのような一例である。

\section{症例 150 代女性 (意味性認知症) $)^{13}$}

この症例は、ものの名前が出てこないことで 異常に気づき神経内科を受診した。発症後も日 常生活上の動作は保たれ、家業の飲食店での調 理や客対応、近所のスーパーマーケットでの惣 菜作りも可能であった。また家族を連れて長距
離をドライブすることも可能であった。一方で、 神経心理学的な検査では失語症状が明らかで、 日常的にもコミュニケーションが制限された状 態になっていた。症状は、言葉の意味が失われ る語義失語と呼ばれるもので、発話や理解は概 ね保たれているように見受けられたが、単語の 意味が失われており、「バナナ」や「斧」など単 語を聞いても、それが何を指すのか分からない 状態であった。一方で、絵を描かせると写実性 が高い絵を描くようになっていた（図2）。細部 の描写も精密であり、色使いも複数の色を合わ せた独特の手法を用いるようになっていた。

このような例は前頭側頭型認知症、特に意味 性認知症において認められることが多い変化で ある。なぜこのような描画になるのであろうか。

ある絵画の技法のテキストには、写実的に描 けるようになるためには、シンボルや象徵体系 を迂回して描くことが推奨されている ${ }^{14}$ 。すな わち、私たちは日常的には対象を見ているよう ではあってもそれを正しく見ているのではなく、 意味や概念のフィルターを通して見ているよう である。たとえば普段の私たちは「草は緑色」 や「家は壁や屋根で構成される」などを既に知っ ているため、そのことが描画にも反映されるよ うである。一般的にはトレーニングによって、 このような象徵体系とは異なった体系を用いた 知覚が可能となり写実性が向上するようだが、 このような症例は、意味や概念が障害されたた めに、結果としてシンボルや象徵体系を迂回し た知覚によって世界を見ているために、このよ 


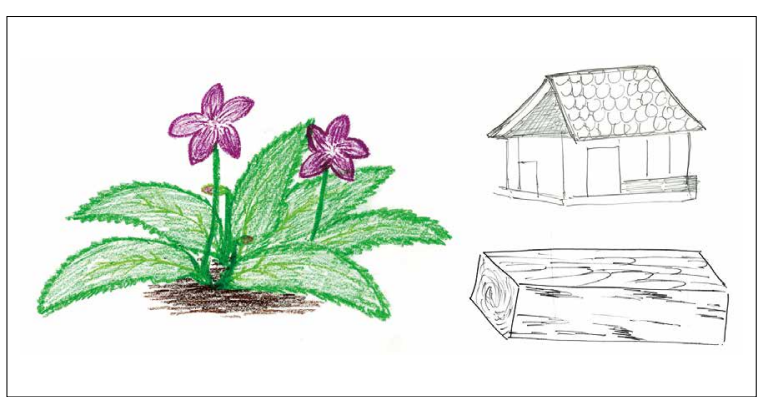

図2 意味性認知症患者の描画（文献 [13]より） 言語機能が障害されても写実性の高い絵を描 くことが可能である。

うな描画となったのかもしれない。なお、意味 性認知症では描画の他にもジグソーパズルなど においても、一般の方々よりも優れた成績を示

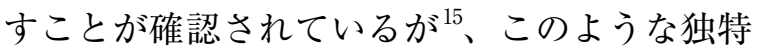
な知覚体系によって実現している可能性がある。

以上のように、描画を通じて、認知症の方々の 見ている世界を垣間見ることができるのである。

\section{3 行動から見えてくること}

認知症の症状は、脳の疾患を直接的な背景と した認知機能障害である中核症状と、認知症に
介入によって反応し、症状が改善することが知 られている ${ }^{\circ}$

周辺症状の発現には外的刺激がきっかけと なることがあり、その背景の一つとして感覚の 変化（感覚過敏）が挙げられる。例えば、ある PCAの症例は、それまで穏やかに過ごしていた が、ある時からそれまで好きだった孫たちが騒 ぐことに耐えきれず、怒り出してしまうという ことが、家族から報告されていた。家族は、聴 覚の鋭敏化が原因だと思い、静かな離れに移動 させて過ごすようにしたところ、状態は安定し、 その後に怒ることはなくなったということで あった。実際、多くの認知症の家族に調查を行 うと、アルツハイマー病、前頭側頭型認知症の

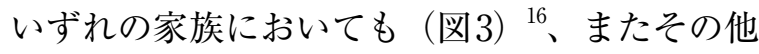
のタイプの認知症の家族においても ${ }^{17}$ 、発症後に 感覚の過敏性が増加することが報告されている。

また、PCAの症例の中には、見えの困難を訴 えることがあるが、これらの訴えの背景には、 私たちの想像を遙かに超えた主観的な世界を体 験していることがある。

伴う行動異常および心理症 状である周辺症状（近年で は「認知症の行動・心理症 状」と呼ばれている）に分 けられる。周辺症状には、 幻覚や妄想、あるいは徘徊 や攻撃行動などが含まれる が、中核症状の改善が困難 であっても、このような周 辺症状は薬物や非薬物的な

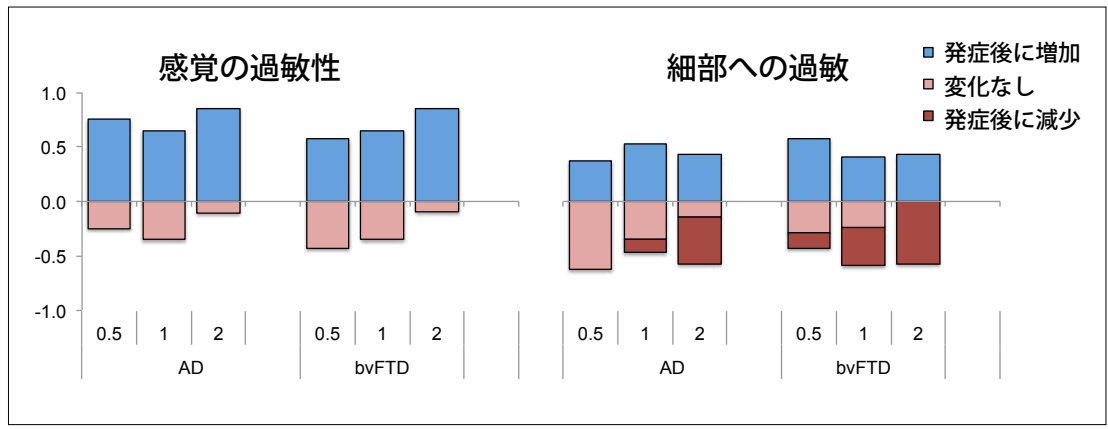

図3 認知症発症後に增減する性質（文献[16]を一部改变） AD：アルツハイマー病、bvFTD：前頭側頭型認知症（行動異常型） 病因にかかわらず過敏性は認知症を発症してから多くの家族で増加し た性質として報告されている。 


\section{症例 260 代 男性（PCA） ${ }^{18}$}

症例は、評価の時点では症状が進 み盲のような振る舞いで、日常的に も移動には家族の介助が必要であっ た。しかし全く見えていないのでは なく、周囲の状況が私たちとは異なっ たように映るようである。特に様々 な什器がある室内は身動きが取れな いようであり、常に介助が必要であっ た。また、デパートの入り口など光 沢のある大理石の床を怖がったりす ることもあった。しかし不思議なこ とに、動く対象の認識や自らが動く と行動はスムーズでキャッチボール や自転車での走行も可能であった ${ }^{18}$ 。

視覚情報の中でも運動情報の有無 によって行動の変化を示すこのよう な症例は、私たちにとっては普段なにげなく見 えている世界が実は複雑な視覚処理によって成 立し、認知症の人々の中には、私たちとは異なっ た知覚経験があることにまで、思いを巡らす必 要があることをも教えてくれる。

認知症の方々が示す行動は、このような知覚 の変化だけではなく、その方々の嗜好や志向を 反映したより認知的な側面についても理解の一 助となることがある。

\section{症例 360 代 女性（前頭側頭型認知症） 19,20}

症例は、急速に認知機能の低下を認め、前頭 葉の萎縮や機能低下も著明であった。自発性も
著しく損なわれ、促すことによって歩行や食事 などがかろうじて可能な状態であった。しかし、 手指の巧緻性は良好でハサミを器用に扱うこと が可能であった。そこで星形の紙を手渡すと一 寸違わず切り取ることが可能であるばかりか、 白紙の用紙を手渡すとガイドが無い状態でも直 線的に長方形を切り取ることが可能であった。 その上、長方形の幅を一定の規則性に則って切 り取ることまで可能であった（図4）19。また散 歩場面では移動経路に嗜好が反映され、小径な どに対する喏好性も確認されている ${ }^{20}$ 。

以上のように普段の行動の観察やその背景と 
なる要因を分析することによって、認知症の方々 の理解や適応的な状況を導き出すことにもつな がる。

\section{視線から見えてくること}

認知機能が低下し、自発的な行動が著しく損 なわれた状態では、これまでのようなアプロー チには限界がある。しかしそのような場合であっ ても、介護者の中には残された僅かな視線の動 きから当事者たちの内的状態を理解しようとす ることがある。これまでにも筋萎縮性側索硬化 症（Amyotrophic Lateral Sclerosis; ALS）の患 者では眼球運動を用いたコミュニケーション手 法が実用化されているが21、認知症においても 眼球運動による認知機能の計測が可能かもしれ ない。しかし、多くのALS患者では認知機能が 保たれていること、随意的な眼球運動が保たれ

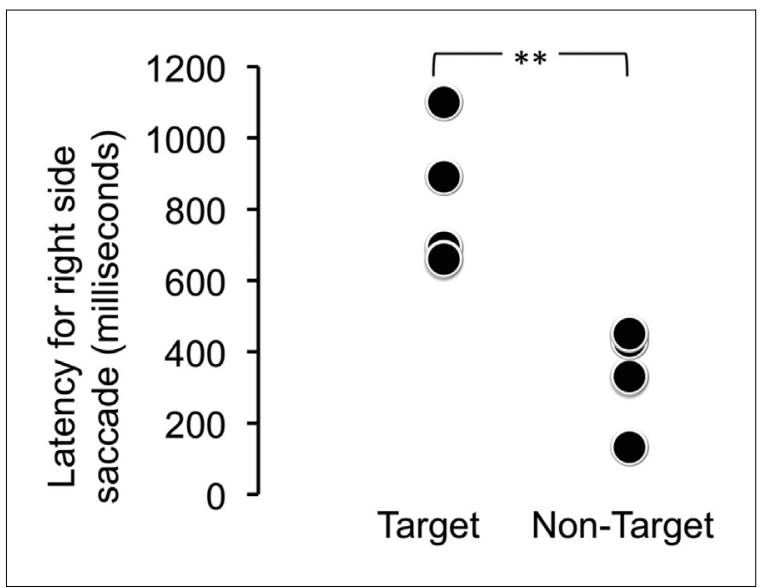

図5 重度の認知症患者における直前に学習した顔 (Target) と新規な顔（Non-Target）に対する眼 球運動（サッケード）の潜時（文献 [22]より） 能動的な視線や注視時間の長さによる差は確認 することができなかったが、サッケード潜時に おいて差を確認することができた。
ていることが前提となって、眼球運動によるコ ミュニケーションが可能となるが、症状が進ん だ認知症では認知機能の低下もあり、意図的な 表出そのものが困難であると予想される。そこ で教示の必要がなく選好のみで認知機能の測定 が可能な選好注視法を用いて症例 3 の人物の弁 別能力を測定したところ、刺激に応じた随意的 な眼球運動は確認されなかったが、受動的な眼 球運動では刺激に応じて変化することが確認さ れた（図5） ${ }^{22}$ 。また変性疾患によって長期入院 の患者に対して同様の試みを行ったところ、実 際の人物を刺激として提示することによって、 より確実に人物に対する選好が計測可能である ことも確認されている ${ }^{23}$ 。

このように生理学的な指標も組み込むことに よって、一般的な神経心理学的検査では困難な 認知症患者の残存機能に接近することが可能と なる。

\section{残された機能に目を向ける}

認知症の診断規準でも示されたように(表1) 4 認知症は認知機能の低下によって判断され、神 経心理学的検査もその一役を担っている。しか し、神経心理学評価はそのような認知機能障害 の顕在化だけではなく、障害を免れた機能の確 認もその目標に揭げられている（表2） ${ }^{24}$ 。また 認知症の障害は本人だけではなく、その家族や 介護者においても障害された認知機能に焦点が 当てられることが多いが、神経心理学的評価は そのような障害されていない機能を含め、本人 
1. 認知システムのどの要素に機能障害があり，この機能障害の重症度はどの程度なのか，また同様に重要な点之

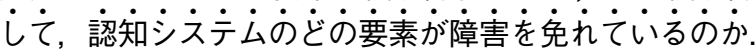

2. 気分や態度, パーソナリティにどの程度の変化がみられるのか. そして，これらの変化のうち，どの程度が損 傷や疾患に対するクライエントの反応ではなく，神経学的損傷の直接的影響によるものと思われるのか.

3. 認知や気分, 態度における变化が, クライアントの現在と当面の日常生活にどのような影響を与えているのか.

4. 認知能力の強弱のパターンと気分や態度による变化にもとづき，正式なリハビリテーションのデザインに関し

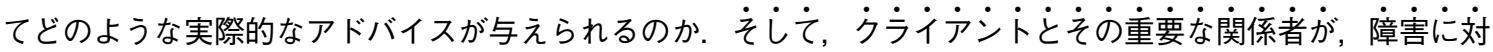

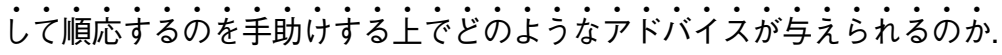

や介護者が障害に対して順応するのを手助けす ることも大切な役割と言える。たとえば、ある 介護者は、テレビインタビューのなかで次のよ うに語ったことがある ${ }^{25}$ 。

初期の頃というのは、正常な状態があって、そ こから変化しているので、「何でこういうこと が分からないのだろう」という認識があった が、（症状が進んだあとは）病状を認識した 上で、「どれくらいのことがまだ分かるだろう か」という切替え方にしました。

また、このように認識することによって、「(介 護が）楽になりました」とも述べていた。その 後のインタビューで、なぜそのような切替え方 が出来るようになったのか尋ねたことがあった が、そのきっかけが、検査場面で“できること” を見せられたことであったそうである。

認知症は認知機能の低下に焦点が当てられる ことが多いが、それでも多くの残された機能が ある。このように認知症患者の残存機能を顕在 化する試みは、語ることができない患者の理解
になるだけではなく、そのような取り組みやそ こで示されたことを通じて、介護者による理解 にもつながると言えよう。

謝辞：本研究はJSPS科研費 18 H 03663 、 15K04191、22730587、および中央大学 共同研究費、特定課題研究費の助成を受 けたものです。

文献

1 本田美和子, イヴ・ジネスト, ロゼット・マレスコッティ . ユマニチュード入門. 東京: 医学書院; 2014.

2 Boden C. Who will I be when I die? Sydney: HarperCollins Publishers; 1997.

3 佐藤雅彦. 認知症になった私が伝えたいこと. 大月書店; 2014

4 日本精神神経学会 (日本語版用語監修), 高橋三郎/大野裕 (監訳). DSM-5 精神疾患の診断・統計マニュアル. 東京: 医学書院; 2014.

5 日本神経学会. 認知症疾患診療ガイドライン2017. 医学書 院; 2017.

6 Wilson RS, Boyle PA, Yu L, Barnes LL, Sytsma J, Buchman AS, Bennett DA, Schneider JA. Temporal course and pathologic basis of unawareness of memory loss in dementia. Neurology. 2015 15;85(11):984-91.

7 Tang-Wai DF, Graff-Radford NR, Boeve BF, Dickson DW, Parisi JE, Crook R, Caselli RJ, Knopman DS, Petersen RC. Clinical, genetic, and neuropathologic characteristics of posterior cortical atrophy. Neurology. 2004;63(7):1168-74. 
8 Mendez MF, Ghajarania M, Perryman KM. Posterior Cortical Atrophy: Clinical Characteristics and Differences Compared to Alzheimer's Disease. Dement Geriatr Cogn Disord. 2002;14(1):33-40.

9 緑川晶. アルツハイマー病の多様性 Posterior cortical atrophy （PCA）とアルツハイマー病. 老年精神医学雑誌. 2015;26(8): 859-66.

10 Nasreddine ZS, Phillips NA, Bédirian V, Charbonneau S, Whitehead V, Collin I, Cummings JL, Chertkow H. The Montreal Cognitive Assessment, MoCA: A Brief Screening Tool For Mild Cognitive Impairment. J Am Geriatr Soc. 2005;53(4):695-9.

11 Brodaty H, Pond D, Kemp NM, Luscombe G, Harding L, Berman K, Huppert FA. The GPCOG: A New Screening Test for Dementia Designed for General Practice. J Am Geriatr Soc. 2002;50(3):530-4.

12 Borson S, Scanlan J, Brush M, Vitaliano P, Dokmak A. The Mini-Cog: a cognitive 'vital signs' measure for dementia screening in multi-lingual elderly. Int $\mathrm{J}$ Geriatr Psychiatry. 2000;15(11):1021-7.

13 Midorikawa A, Fukutake T, Kawamura M. Dementia and painting in patients from different cultural backgrounds. Eur Neurol. 2008;60(5):224-9.

14 Edwards $B$. The new drawing on the right side of the brain. 3rd, editor. Tarcher; 1999.

15 Green HAC, Patterson K. Jigsaws-A preserved ability in semantic dementia. Neuropsychologia. 2009;47(2):569-76.

16 Midorikawa A, Leyton CE, Foxe D, Landin-Romero R, Hodges JR, Piguet O. All is Not Lost: Positive Behaviors in Alzheimer's Disease and Behavioral-Variant Frontotemporal Dementia with Disease Severity. J Alzheimer's Dis. 2016 6;54(2):549-58.

17 Midorikawa A, Kumfor F, Leyton CE, Foxe D, LandinRomero R, Hodges JR, Piguet O. Characterisation of "Positive" Behaviours in Primary Progressive Aphasias. Dement Geriatr Cogn Disord. 2017;44(3-4):119-128.

18 Midorikawa A, Nakamura K, Nagao T, Kawamura M. Residual perception of moving objects: Dissociation of moving and static objects in a case of posterior cortical atrophy. Eur Neurol. 2008;59(3-4):152-8.

19 Midorikawa A, Kawamura M. Does the brain prefer geometrical homogeneity? Behav Neurol. 2010;23(3):101-5.

20 Midorikawa A, Suzuki H, Hiromitsu K, Kawamura M. Wandering behavior of a severely demented patient with frontotemporal dementia. Neurocase. 2016;22(2):220-4.

21 Beukelman D, Fager S, Nordness A. Communication Support for People with ALS. Neurol Res Int. 2011;16. Available from: http://www.hindawi.com/journals/ nri/2011/714693/

22 Midorikawa A, Itoi C, Kawamura M. Detection of residual cognitive function through non-spontaneous eye movement in a patient with advanced frontotemporal dementia. Front Neurosci. 2014;8:334.
23 Midorikawa A, Shigemune Y, Kawai Y. Detection of residual cognitive functions through passive eye-movement paradigm in patients with advanced dementia. In: 11th International Conference on Frontotemporal Dementia. Sydney; 2018.

24 Beaumont JG, Kenealy P, Rogers M. The Blackwell Dictionary of Neuropsychology. Wiley; 1991. 監訳: 岩田誠, 河内十郎, 河村満; 神経心理学事典, 医学書院; 2007.

25 緑川晶. 知の回廊 第61回『認知症の理解』. 2010. Available from: https://www.youtube.com/watch?v=boNPJ9BfNRs 